\title{
Physico-Chemical and Biological Characteristics of Stagnant Surface Water Bodies (Ponds and Lakes) Used for Drinking and Domestic Purposes in Niger Delta, Nigeria
}

\author{
Akpofure Rim-Rukeh \\ Department of Environmental Science, College of Science, Federal University of Petroleum Resources, Effurun, Nigeria. \\ Email: arimrukeh@yahoo.co.uk \\ Received June $16^{\text {th }}, 2013$; revised July $21^{\text {st }}, 2013$; accepted August $15^{\text {th }}, 2013$ \\ Copyright (C) 2013 Akpofure Rim-Rukeh. This is an open access article distributed under the Creative Commons Attribution License, \\ which permits unrestricted use, distribution, and reproduction in any medium, provided the original work is properly cited.
}

\begin{abstract}
The surface water quality of some stagnant water bodies (ponds and lakes-Obi Lake, Usede pond, Oguta lake, Omuku pond, Ugheghe pond, Karabodone lake, Abua lake, Ikarama lake, Tenmako lake, and Adiegbe lake) in the Niger Delta area of Nigeria have been investigated experimentally by analysing the physico-chemical and biological characteristics of the surface water samples. Results show: $\mathrm{pH}(5.10-7.40)$, temperature $\left(26.4^{\circ} \mathrm{C}-31.0^{\circ} \mathrm{C}\right)$, turbidity $(7.83-27.7 \mathrm{NTU})$, electrical conductivity $(13.5-34.8 \mu \mathrm{S} / \mathrm{cm})$, biochemical oxygen demand (BOD) $(1.07-19.5 \mathrm{mg} / \mathrm{l})$, chemical oxygen demand (COD) $(1.90$ - $21.5 \mathrm{mg} / \mathrm{l})$, suspended solids (SS) $(9.70-37.3 \mathrm{mg} / \mathrm{l})$, dissolved oxygen (DO) $(2.7-8.7 \mathrm{mg} / \mathrm{l})$, total dissolved solids (TDS) $(33.8-187.0 \mathrm{mg} / \mathrm{l})$, total phosphorus $(0.73-2.47 \mathrm{mg} / \mathrm{l})$, ammoniacal nitrogen (AN) $(0.018$ - $4.70 \mathrm{mg} / \mathrm{l}$ ) and total fecal coliform count (TFCC) (nil - $2175 \mathrm{cfu} / \mathrm{ml})$. Results on the water quality using Malaysian Water Quality Index (WQI) show that Usede pond and Obi Lake belong to Class II with values that are 75.24 and 76.73 respectively. The WQI of Oguta lake, Omuku pond, Ugheghe pond, Karabodone lake and Abua lake are 67.46, 65.64, 65.87, 50.77, and 67.01 respectively and belongs to class III. The WQI of Ikarama lake, Tenmako lake, and Adiegbe lake are $43.38,37.60$, and 41.40 , respectively and belongs to class IV and is described as fair.
\end{abstract}

Keywords: Malaysian Water Quality Index; Sewage; Drinking Water; Ponds; Lakes; Class II Water; Class III Water; Class IV Water

\section{Introduction}

Water is an indispensable resource for the world economy as well as a precondition for human, animal and plant life, as there can be no stability of health and wellbeing without safe and adequate water supply. Water is a universal solvent dissolving a number of substances that it comes in contact with. However, water for human consumption and other domestic purposes should be free from disease causing organisms, poisonous substances and excessive amounts of mineral and organic matter. It should also be free from colour, turbidity, taste and odour.

The problem of potable water shortage has become a serious matter in the world from local to global perspective and has commanded a dramatic attention. It is reported that about 80 countries of the world now have water shortage and this is reflecting through their health and economies, while $40 \%$ of the World population has no access to clean water or sanitation [1]. This condition is worse in developing countries. In Nigeria for example, safe water is an important national political issue especially in the rural areas. In most urban and rural settings major sources of water for drinking and domestic purposes are rivers/creeks/streams/ponds, hand-dug wells and harvested rain water [2].

Several studies have documented the detection of coliforms, heterotrophic bacteria and hydrocarbon utilizing bacteria (HUB) in rivers and streams in the Niger Delta area [3-5]. Studies on the physico-chemical and biological composition of stagnant surface water bodies such as ponds and lakes are still scarce and limited. This paper presents a study on the physico-chemical and bio- 
logical characteristics of stagnant surface water bodies (ponds and lakes) used for drinking and domestic purposes in the Niger Delta area of Nigeria. The quality of such sources of water was also assessed using Malaysian Water Quality Index (WQI). The use of water quality indices (WQI) is a common practice to circumvent the intrinsic difficulty of assessing overall quality standard involving a certain set of water bodies. Water quality indices are intended to provide a simple but reliable tool for managers and decision makers on the quality of water for a wide range of uses for a given set of water bodies [6].

\section{Materials and Methods}

\subsection{Study Area}

The study area is the Niger Delta region of Nigeria. It is located within Latitude $5^{\circ} 45^{\prime}-6^{\circ} 35^{\prime}$ and Longitude $4^{\circ} 50^{\prime}$ $-5^{\circ} 15^{\prime}$ in the southern part of the country. Geopolitically, the Niger Delta comprised of oil producing states of; Abia, Akwa-Ibom, Bayelsa, Cross-River, Delta, Edo, Imo, Ondo and Rivers (Figure 1). It covers an estimated area of about $70,000 \mathrm{~km}^{2}$ which accounts for about 8 percent of Nigeria's land mass [7]. The petroleum Industry in Nigeria is located in the Niger Delta area, with distribution of oil fields. The area accounts for about 90 percent of Nigeria's gross earnings as the production and exports of oil and gas play a dominant role in her economy [7].

Previous study of the meteorology of the area [8], reveals the average atmospheric temperature to be $25.50^{\circ} \mathrm{C}$ in the rainy season and $30.00^{\circ} \mathrm{C}$ in the dry season. The daily relative humidity values range from 55.50 percent in dry season to 96.00 percent in rainy season. Rainfall in the area averages $2500 \mathrm{~mm}$ annually. The rainfall pattern shows two identifiable seasons; the rainy season (April to October) and the relatively short dry season (November to March).

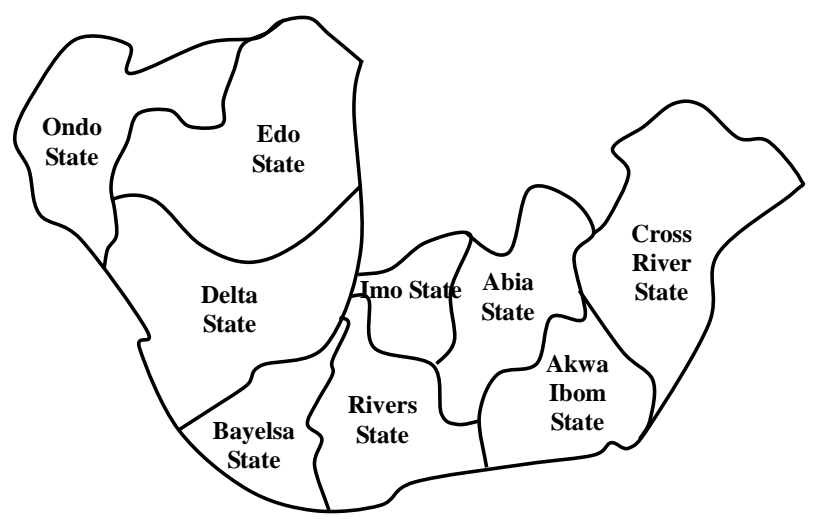

Figure 1. Geopolitical map of the Niger Delta Area.
The area is a vast flood plain built by accumulation of sedimentary deposits washed down the Niger and Benue rivers. The Niger Delta area is the largest wetland in West Africa and one of the largest mangrove forests in the world [9]. The area is criss crossed with numerous rivers, streams, tributaries, creeks and creeklets. Human settlement pattern is linear along the bank of the rivers.

\subsection{Methodology}

10 (ten) stagnant surface water bodies (ponds and lakes) that serve as the source of water for domestic and drinking purposes were selected within the study area. All sampling points were geo-referenced (Table 1).

Water for the study was sampled according to the method of [10]. A stainless steel water sampler was used to collect surface water samples of the selected locations. The samples collected from 5 (five) random points within each location were taken to the laboratory for analyses. At each of the sample collection sites, a record was kept on the sample container indicating date, time, and location of sampling. Samples were properly handled and all necessary quality assurance and quality control (QA/QC) measures such as preservation, storage, and labeling, were taken. All sample containers were pretreated by washing in dilute hydrochloric acid and rinsed with distilled water. Winklers bottles were used to collect samples for BOD measurements. Fast changing parameters such as $\mathrm{pH}$, temperature, dissolved oxygen (DO), total dissolved solids (TDS), turbidity and electrical conductivity were measured in-situ using a multi-parameter water quality monitor (model 6000 UPG). At the determination of any of these parameters the instrument was properly checked and calibrated. All water samples for the study were collected within the late rainy season (September - October) of 2012 and taken to Federal University of Petroleum Resources, Department of Environmental Sciences Laboratory for analysis.

In the laboratory, samples were analyzed for: BOD (biochemical oxygen demand), COD (chemical oxygen demand), SS (Suspended solids), ammonical nitrogen (AN), total phosphorus (TP) and TFCC (total fecal coliform counts). TSS was determined using the mass loss technique (APHA 209D-Total Non-filtrate Residual Dried at $103^{\circ} \mathrm{C}-105^{\circ} \mathrm{C}$. The oven dried $\left(\right.$ at $105^{\circ} \mathrm{C}$ for 1 hour) filter paper was used instead of glass fibre filter. The dried filter paper was weighed and then used to filter $100 \mathrm{ml}$ of the sample. The filter paper and the residue were then dried in the oven at $105^{\circ} \mathrm{C}$ for 1 hour and allowed to cool. The paper and residue was then weighed and recorded). BOD was determined using iodometric method while Ammonical Nitrogen was determined using Brucine colourimeter method. Total phosphate (TP) was determined using spectrophotometric method. For 
ecal coliform samples, 3 dilutions were prepared and analyzed by the membrane filtration method in triplicate. All methods of analyses were consistent with [11-13].

The water quality at each of the sampling location was assessed using the Malaysian Water Quality Index (WQI) as reported [14]. Equation (1) gives the water quality index. The index considers six parameters. The parameters which have been chosen are dissolved oxygen (DO), biological oxygen demand (BOD), chemical oxygen demand (COD), total suspended solid (TSS), $\mathrm{pH}$ value (pH), and ammonical nitrogen (AN) [15]. The parameters and the weightage were assigned to each parameter.

The WQI approved by the Malaysian DOE (Equation (1)) is calculated based on the above six parameters. Among them DO carries maximum weightage of 0.22 and $\mathrm{pH}$ carries the minimum of 0.12 in the WQI equation.
The WQI equation eventually consists of the subindexes, which are calculated according to the best-fit relations given in Equations (2)-(7). The formulas used in the calculation of WQI are:

$$
\begin{aligned}
\mathrm{WQI}= & 0.22 \mathrm{SI}_{\mathrm{DO}}+0.19 \mathrm{SI}_{\mathrm{BOD}}+0.16 \mathrm{SI}_{\mathrm{COD}} \\
& +0.16 \mathrm{SI}_{\mathrm{TSS}}+0.15 \mathrm{SI}_{\mathrm{AN}}+0.12 \mathrm{SI}_{\mathrm{pH}}
\end{aligned}
$$

where,

WQI = Water quality index (dimensionless unit);

$\mathrm{SI}_{\mathrm{DO}}=$ Sub-index of DO;

$\mathrm{SI}_{\mathrm{BOD}}=$ Sub-index of BOD;

$\mathrm{SI}_{\mathrm{COD}}=$ Sub-index of COD;

$\mathrm{SI}_{\mathrm{AN}}=\mathrm{Sub}$-index of AN;

$\mathrm{SI}_{\mathrm{TSS}}=$ Sub-index of TSS;

$\mathrm{SIpH}=$ Sub-index of $\mathrm{pH}$.

Sub-index for DO (in \% saturation):

Sub-index for BOD:

$$
\mathrm{SI}_{\mathrm{DO}}= \begin{cases}0 & \text { for } \mathrm{DO}<8 \\ 100 & \text { for } \mathrm{DO}>92 \\ -0.395+0.030 \mathrm{DO}^{2}-0.00020 \mathrm{DO}^{3} & \text { for } 8<\mathrm{DO}<92\end{cases}
$$

Sub-index for COD:

$$
\mathrm{SI}_{\mathrm{BOD}}= \begin{cases}100.4-4.23 \mathrm{BOD} & \text { for BOD }<5 \\ 108 \mathrm{e}-0.055 \mathrm{BOD}-0.1 \mathrm{BOD} & \text { for BOD }>5\end{cases}
$$

$$
\mathrm{SI}_{\mathrm{COD}}= \begin{cases}-1.33 \mathrm{COD}+99.1 & \text { for } \mathrm{COD}<20 \\ 103 \mathrm{e}-0.0157 \mathrm{COD}-0.04 \mathrm{COD} & \text { for } \mathrm{COD}>20\end{cases}
$$

Sub-index for AN:

$$
\mathrm{SI}_{\mathrm{AN}}= \begin{cases}100.5-105 \mathrm{AN} & \text { for } \mathrm{AN}<0.3 \\ 94 \mathrm{e}-0.573 \mathrm{AN}-5(\mathrm{AN}-2) & \text { for } 0.3<\mathrm{AN}<4 \\ 0 & \text { for } \mathrm{AN}>4\end{cases}
$$

Sub-index for TSS:

$$
\mathrm{SI}_{\mathrm{TSS}}= \begin{cases}97.5 \mathrm{e}-0.00676 \mathrm{SS}+0.05 \mathrm{SS} & \text { for } \mathrm{SS}<100 \\ 71 \mathrm{e}-0.0016 \mathrm{SS}-0.015 \mathrm{SS} & \text { for } 100<\mathrm{SS}<1000 \\ 0 & \text { for } \mathrm{SS}>1000\end{cases}
$$

Sub-index for $\mathrm{pH}$ :

$$
\mathrm{SI}_{\mathrm{pH}}= \begin{cases}17.2-17.2 \mathrm{pH}+5.02 \mathrm{pH}^{2} & \text { for } \mathrm{pH}<5.5 \\ -242+95.5 \mathrm{pH}-6.67 \mathrm{pH}^{2} & \text { for } 5.5<\mathrm{pH}<7 \\ -181+82.4 \mathrm{pH}-6.05 \mathrm{pH}^{2} & \text { for } 7<\mathrm{pH}<8.75 \\ 536-77.0 \mathrm{pH}+2.76 \mathrm{pH}^{2} & \text { for } \mathrm{pH}>8.75\end{cases}
$$

Based on the Malaysian WQI, water quality is classified according to one of the following categories shown in the Table 2.

Generally, based on Malaysian WQI water quality is classified as follows:

WQI Quality of water

91-100 Excellent
71 - 90 Good;

51 - 70 Medium or average;

26 - 50 Fair;

0 - 25 Poor.

\section{Results and Discussion}

Results indicating the physico-chemical and biological 
(Ponds and Lakes) Used for Drinking and Domestic Purposes in Niger Delta, Nigeria

Table 1. Studied Surface Water Bodies (Ponds and Lakes) in the Niger Delta Area.

\begin{tabular}{|c|c|c|c|c|c|}
\hline \multirow{2}{*}{$\mathrm{S} / \mathbf{N}$} & \multirow{2}{*}{ Location/Community } & \multicolumn{2}{|c|}{ Coordinates } & \multirow{2}{*}{ Local Government Area/State } & \multirow{2}{*}{ Native name of the water body } \\
\hline & & Northing & Easting & & \\
\hline 1 & Okorobi & 195509.06 & 379922.04 & Ethiope East/Delta & Obi Lake \\
\hline 2 & Ikarama & 143242.16 & 474506.31 & Yenagoa/ Bayelsa & Ikarama Lake \\
\hline 3 & Asaba-Ase & 249629.18 & 416242.11 & Ndokwa East/Delta & Usede Pond \\
\hline 4 & Ovierie -Ovu & 195571.16 & 379929.07 & Ethiope East/ Delta & Omoku Pond \\
\hline 5 & Ugheghe & 195593.18 & 379935.02 & Ughelli South/ Delta & Ame - Oghene \\
\hline 6 & Abua & 837841.72 & 478189.55 & Abua-Odua/Rivers & Abou Lake \\
\hline 7 & Oguta & 178000.33 & 470500.12 & Oguta/Imo & Oguta Lake \\
\hline 8 & Tenmako & 119120.82 & 388021.02 & Southern Ijaw/Bayelsa & Tenmako Lake \\
\hline 9 & Karabodone & 126335.11 & 386066.50 & Ekeremor/Bayelsa & Karabodone Lake \\
\hline 10 & Adiegbe & 127743.28 & 387928.30 & Ekeremor/Bayela & Adiegbe Lake \\
\hline
\end{tabular}

Table 2. Classes in Malaysian Water Quality Index [14].

\begin{tabular}{cccccc}
\hline \multirow{5}{*}{ Parameter Class } \\
\cline { 2 - 6 } & I & II & III & IV & V \\
\hline AN & $<0.1$ & $0.1-0.3$ & $0.3-0.9$ & $0.9-2.7$ & $>2.7$ \\
BOD & $<1$ & $1-3$ & $3-6$ & $6-12$ & $>12$ \\
COD & $<10$ & $10-25$ & $25-50$ & $50-100$ & $>100$ \\
DO & $>7$ & $5-7$ & $3-5$ & $1-3$ & $<1$ \\
pH & $>7$ & $6-7$ & $5-6$ & $<5$ & $<5$ \\
TSS & $<2.5$ & $25-50$ & $50-150$ & $30-50$ & $>300$ \\
WQI & $>92.7$ & $76.5-92.7$ & $51.9-76.5$ & $31-51.9$ & $<31.0$ \\
\hline
\end{tabular}

characteristics of the stagnant surface water bodies (ponds and lakes) are presented in Table 3.

From the results (Table 3 ), the $\mathrm{pH}$ of surface water samples vary from slight acidity to neutrality with mean values between 5.10 and 7.40. The acidic $\mathrm{pH}$ may have resulted from humic acid (HA) formed from decaying organic matter which is consistent with the report of the Niger Delta swamp environment $[16,17]$. The acidic $\mathrm{pH}$ range appears to be suitable for the survival of freshwater fish and bottom dwelling invertebrates [18]. pH affects many chemical and biological processes, for example low $\mathrm{pH}$ permits toxic elements and compounds to become mobile and available for uptake by aquatic plants and animals [19].

The temperature of a water body is an important water quality parameter because excessive temperature $\left(>35^{\circ} \mathrm{C}\right)$ through the addition of heated liquid effluents to water bodies alters the state of the recipient body in a number of waters. High temperatures increases the level of turbidity and invariably results to reduce rate of light penetration and this in turn off sets photosynthetic process of phytoplanktons (the beginners of food chain) which is the primary food link between fry and fingerlings and the adult fish. A high temperature increases the metabolic rate of aquatic organisms and causes a reduction in the level of dissolved oxygen (DO). This may retard the growth and reproduction of fish and in severe condition result to death of marine life. High temperatures cause suspended solid to settle at a faster rate (2.5 times faster at $35^{\circ} \mathrm{C}$ than at $0^{\circ} \mathrm{C}$ ). Density and viscosity of water will also reduce at higher temperatures.

Temperature values recorded in the surface water samples ranged from $26.4^{\circ} \mathrm{C}$ to $31.0^{\circ} \mathrm{C}$. The variability in temperature values in the surface water bodies may have resulted from the weather condition of the sampling points at the time of the study.

Turbidity is the cloudiness or haziness of a fluid caused by individual particles (suspended solids) that are generally invisible to the naked eye. The measurement of turbidity is a key test of water quality. Turbidity is an optical property relating to light adsorption and scattering in water. It is an important parameter because it affects the penetration of sunlight into the water body. The turbidity of the surface water bodies ranged between 7.83 and 27.7 Nephelometric Turbidity Units (NTU) which is above regulatory limits of $5 \mathrm{mg} / 1$ [12]. This relatively high turbidity accounts for non visibility of the bed of the surveyed ponds and lakes from the surface. This may also affect the transmission of light rays of the sun and hence have effect on the bottom dwelling phytoplankton. The higher turbidity values are to the presence of humic substances resulting from decaying organic matter and 


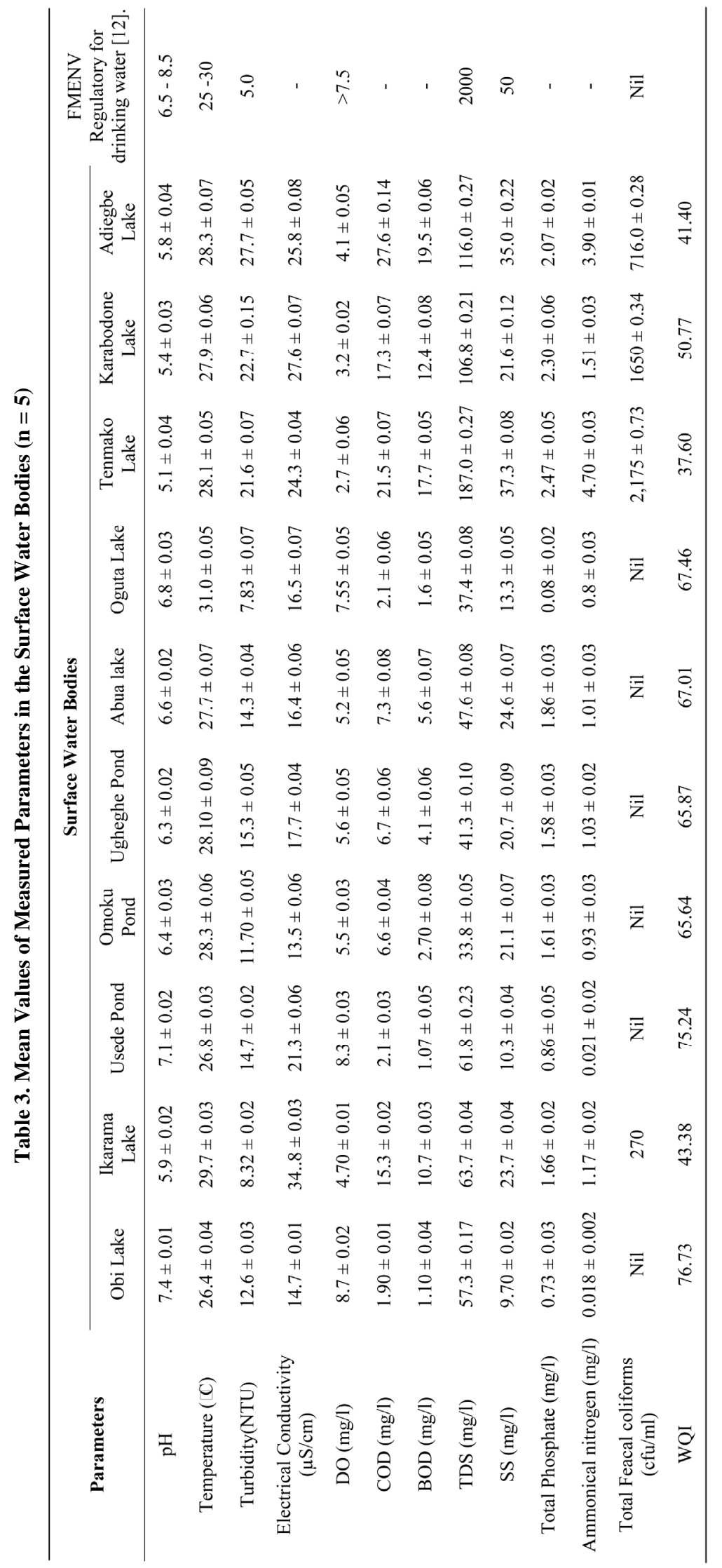


runoff especially during the rainy season.

Electrical conductivity refers to the specific electrical conductance of water i.e. the ability of water to pass electric current. The conductivity of water in $\mu \mathrm{S} / \mathrm{cm}$ is roughly proportional to the concentration of dissolved solids (mostly inorganic salts) it contains. Thus conductivity is important in ecology and environmental management as an indicator of the total dissolved inorganic salts and other solids in water. Electrical conductivity of the surface water samples ranged between 13.5 and 34.8 $\mu \mathrm{S} / \mathrm{cm}$. The low values of electrical conductivity may be attributed to the freshwater nature of the water bodies as have been similarly reported [20].

A good level of dissolved oxygen is essential for aquatic life. It is an important parameter in water quality assessment. The concentration of DO vary daily and seasonally and depends on the species of phytoplankton present, light penetration, nutrient availability, temperature, salinity, water movement, partial pressure of atmospheric oxygen in contact with the water, thickness of the surface film and the bio-depletion rates [21]. The DO levels of the surface water bodies ranged between 2.7 and $8.70 \mathrm{mg} / \mathrm{l}$. DO value for fresh water depends upon the temperature, and its value varies from $14.62 \mathrm{mg} / \mathrm{l}$ at $0^{\circ} \mathrm{C}$ to $7.63 \mathrm{mg} / \mathrm{l}$ at $30^{\circ} \mathrm{C}$ (at normal atmospheric pressure). DO levels below $5.0 \mathrm{mg} / 1$, aquatic life is put under stress and could result in large fish kills if sustained for a few hours [21]. The DO levels in Ikarama, Tenmako, Karabodone and Adiegbe lakes provide a poor condition for the survival for aquatic life [22]. The observed DO levels at these points may have resulted from the biodegradation of organic waste such as sewage.

Total Dissolved Solids (TDS) are the total amount of mobile charged ions, including minerals, salts or metals dissolved in a given volume of water. TDS is directly related to electrical conductivity of water as;

$$
\operatorname{TDS}(\mathrm{mg} / \mathrm{L})=\mathrm{EC}\left(\mu \mathrm{S} / \mathrm{cm} \text { at } 25^{\circ} \mathrm{C}\right) \times 0.6
$$

TDS level in the surface water samples ranged between $33.8 \mathrm{mg} / 1$ and $187.0 \mathrm{mg} / \mathrm{l}$. As a rough estimation, freshwater may be considered to have TDS of $1500 \mathrm{mg} / \mathrm{l}$; brackish water, $5000 \mathrm{mg} / \mathrm{l}$ and saline water, above 5000 $\mathrm{mg} / \mathrm{l}$ and sea water TDS values lie between 30,000 and $34,000 \mathrm{mg} / \mathrm{l}$. The recommended maximum value for surface water bodies is $2000 \mathrm{mg} / \mathrm{l}$ [23].

Suspended solids (SS) consists of an inorganic fraction (silts, clays, etc) and an organic fraction (algae, zooplankton, bacteria, and detritus) that are carried along by water as it runs off the land and these contribute to the turbidity or cloudiness of a water body [24]. Suspended solids can clog fish gills, resulting in either fish death or reduction in growth rate. They also reduce light penetration, thereby reducing the ability of algae to produce food and oxygen. A positive effect of the presence of suspended solids in water is that toxic chemicals such as pesticides and metals tend to adsorb to them or become complexes with them thereby making the toxics less available for absorption by living organisms. In a study in which SS was increased to $80 \mathrm{mg} / 1$, the macro invertebrate population was decreased by $60 \%$ [24]. SS level in the surface water samples were between $9.70 \mathrm{mg} / \mathrm{l}$ and $37.3 \mathrm{mg} / \mathrm{l}$. The obtained levels of TSS may have resulted from presence of silt and other suspended materials observed in the water body.

Biochemical oxygen demand (BOD) is the amount of oxygen required by microorganisms to stabilize decomposable organic matter at a particular time and temperature. BOD test is widely used to determine the pollutional strength of domestic and industrial wastes in terms of the oxygen that they require to deliver end products as $\mathrm{CO}_{2}$ and $\mathrm{H}_{2} \mathrm{O}$. Most pristine rivers will have a 5-day BOD below $1 \mathrm{mg} / \mathrm{l}$. Moderately polluted rivers may have a BOD value in the range of 2 to $8 \mathrm{mg} / \mathrm{l}$. Municipal sewage that is efficiently treated by a three stage process would have a value of about $20 \mathrm{mg} / \mathrm{l}$. Untreated sewage varies, but averages around $600 \mathrm{mg} / \mathrm{l}$ in Europe and as low as $200 \mathrm{mg} / \mathrm{l}$ in the United State, or where there is severe groundwater or surface water infiltration [11]. BOD level in the surface water samples was between $1.07 \mathrm{mg} / \mathrm{l}$ and $19.5 \mathrm{mg} / \mathrm{l}$. Using the BOD values as standard for evaluating the water body, the water quality most of these water bodies may be described as heavily polluted.

COD is the amount of (dissolved) oxygen required to oxidize and stabilize (organic and inorganic content of) the sample solution. It is used to measure the content of oxidizable organic as well as inorganic matter of the given sample of waters. Chemical oxygen demand is related to biochemical oxygen demand (BOD), another standard test for assaying the oxygen-demanding strength of waste waters. The COD of a waste is higher than the BOD because more compounds are chemically oxidized in a short interval of time. It had the advantage of getting completed in 3 hours compared to 5 days of the BOD test. It is possible to correlate $\mathrm{BOD}$ and $\mathrm{COD} . \mathrm{BOD}_{5} / \mathrm{COD}$ ratio is called Biodegradability Index and varies from 0.4 to 0.8 for domestic wastewaters. If $\mathrm{BOD} / \mathrm{COD}$ is $>0.6$ then the waste is fairly biodegradable and can be effecttively treated biologically. If BOD/COD ratio is between 0.3 and 0.6 , then seeding is required to treat it biologically. If BOD/COD is $<0.3$ then it cannot be treated biologically. COD level in the surface water samples were between $1.90 \mathrm{mg} / 1$ and $21.5 \mathrm{mg} / \mathrm{l}$. Using the BOD/COD values as standard for evaluating the water quality of the water bodies, they may be classified as highly biodegradable. The obtained COD level in some of the water 
bodies is low compared with $30,000 \mathrm{mg} / \mathrm{l}$ that is reported for starch processing companies [25].

The nutrient content of water is an indication of the degree of sustainability of the system of primary production. At very high concentration of nutrients such as total phosphate and ammonical nitrogen, eutrophication in river bodies may be possible. The ranges of total phosphate and ammonical nitrogen in the study water bodies ranged between $0.73-2.47 \mathrm{mg} / 1$ and $0.018-4.70 \mathrm{mg} / 1$ respectively.

Total fecal coliform count (TFCC) in the water bodies ranged between Nil and $2175(\mathrm{cfu} / \mathrm{ml})$. At Ikarama, Tenmako, Karabodone and Adiegbe lakes the presence of TFCC indicates a point source of contamination which invariably is the visible presence of pier toilet.

Results of the assessment of the water quality of the surface water bodies using the water quality index as reported [14] are presented in Table 3. Using the water quality index, the water quality of Usede pond and Obi Lake defined at the sampling stations belongs to Class II with values that are 75.24 and 76.73 respectively. Empirically, the water quality of these water bodies can be described as good.

The good water quality of Obi pond and Usede Lake may have stemmed from the role of traditional beliefs in the conservation of natural resources [26-28]. Traditional conservation ethics are capable of protecting biodiversity species in particular and the environment in general as long as the local communities have a stake in it. In fact, traditional ecological knowledge (TEK) systems are infused with practices and concepts, and modes of teaching and learning that can be related directly and indirectly to resource stewardship and conservation at various scales.

At the "Obi" pond popularly called Obi Lake, it is believed that the Obi spirit inhabits the water body. There is the traditional Obi cult in the community with a juju priest in charge of offering sacrifices to the Obi god. Usually membership into this group is on strict qualification with terms and condition of membership strictly spelt out and passed down to community members for onward transmission to their children while growing up. Most often the process of initiation is a transitive one, from adolescent to adulthood and done in the night deep inside the shire.

Felling of trees or fuel wood collection within thirty meters radius from the pond is strictly prohibited. This principles though unknown was meant to preserve the watershed and the surrounding vegetation, this conesquently checks the amount of evapotranspiration and allows some amount of tolerable water temperature for both micro and aquatic organisms to continue their ecosystem services for the enrichment of the soil, continuous supply of water and the healthy growth of the forest. The vegetation cover also helped to keep the water cool and fresh for drinking. Bathing and washing of clothes around, near or inside the pond is not allowed. Fishing or harvesting any aquatic animals within the pond is not allowed.

Reasons abound for this law, spanning from the respect for the Obi god who protect the pond and the organisms helping to purifying the pond and keeping the pond alive and also control the spread of diseases. Silence is observed while fetching water from the pond because it is believed that while speaking, an infected person may spill or splash saliva, so an infected person with tuberculosis or whooping cough for example may spill infected saliva containing the bacteria into the water. In addition this rule ensured the gods were not provoked to anger. Their anger could result in lake drying up.

Other taboos, such as the disallowing of menstruating women to collect water from the pond, prevent the defilement of pond deity and the issue of menstrual blood in traditional beliefs has been treated extensively in anthropology as a source of potent force [29].

"Usede" pond is a mysterious pond harvested for fish species by the entire Ase kingdom once in ten years. The Usede pond is such that nobody goes there to fish alone within this period of ten years. Even if you go fishing alone, the punishment begins by having a bloated stomach and later death no matter the sacrifice made. So entrant into the pond alone is frightening. The reverence for the water body because of the presence Usede god prevents community people from using the water resource indiscriminately.

Using the water quality index, the water quality of Oguta lake, Omuku pond, Ugheghe pond, Karabodone lake and Abua lake are 67.46, 65.64, 65.87, 50.77, and 67.01 respectively and belong to class III. Empirically, the water quality can be described as average or medium.

Using the water quality index, the water quality of Ikarama lake, Tenmako lake, and Adiegbe lake are 43.38, 37.60 , and 41.40 respectively and belong to class IV. Empirically, the water quality can be described as fair. Using the BOD/COD values as standard for evaluating the water quality of these water bodies, they may be classified as highly biodegradable. This also indicates a point source of contamination which invariably is the presence of human activities such as sewage recipient.

\section{Conclusions}

The surface water quality of some stagnant water bodies (ponds and lakes) in the Niger Delta Area of Nigeria has been experimentally studied. This is sequel to the fact that most of the water bodies in the study area serve the purpose for drinking and other domestic activities. 
Results of the assessment of the water quality of the surface water bodies at the sampling points indicate that the water quality varies from good to fair through medium. Sewage discharge related water pollution problems were observed at four locations. From the study, there is high risk of water contamination from fecal coliforms on a specific scale and other water quality monitoring parameters on a broad scale.

\section{REFERENCES}

[1] WHO/UNICEF/WSSCC, "Global Water Supply and Sanitation Assessment Report," World Health Organization/ United Nation's Fund, Water Supply and Sanitation Collaborative Council, 2000.

[2] FGN, "Annual Report on Water Resources in Nigeria," A Yearly Publication of Federal Ministry of Water Resources, Federal Government of Nigeria, 2000.

[3] J. Odok, R. Antigha, O. Offiong and A. Edet, "Sources of Nitrates and Bacteria in the Shallow Coastal Plain Sand Aquifer, of Calabar, Nigeria," 2nd Earthwatch Conference on Water, Port Harcourt, 16 - 18 March 2003.

[4] N. C. Ewelike, "The Quality of Njaba River for Domestic Purpose: A Sanitary Assessment," 2nd Earthwatch Confer- ence on Water, Port Harcourt, 16 - 18 March 2003.

[5] A. I. Okoh, G. O. Babalola and M. K. Bakare, "Microbial Densities and Physico Chemical Quality of Some Crude Oil Flow Stations' Saver Pit Effluents in the Niger Delta Areas of Nigeria," Science of the Total Environment, Vol. 30, No. 2, 1996, pp. 73-78. doi:10.1016/0048-9697(96)05123-6

[6] A. A. Bordalo, W. Nilsumranchit and K. Chalermwat, "Water Quality and Uses of the Bangpakong River," Water Research, Vol. 35, No. 15, 2001, pp. 3635-3642. doi:10.1016/S0043-1354(01)00079-3

[7] K. A. B. Okoko and J. N. Nna, "Emerging Trends and Community Perception in the Nigerian Oil Industry," Nigerian Journal of Oil and Politics, Vol. 1, No. 2, 1998, pp. 44-54.

[8] A. E. Gobo, "Meteorology and Man's Environment," African-link Books, Ibadan, 1998.

[9] M. D. Darefaka, "Water Quality Standards and Guidelines in Nigeria," 2nd Earthwatch Conference on Water, Port Harcourt, 16 - 18 March 2003.

[10] S. T. Grassloff, "Sampling Soil and Water for Environmental Studies," Klux Publishers, India, 1983.

[11] APHA, "Standard Methods for the Examination of Water and Wastewater," 20th Edition, American Public Health Association (APHA), American Water Works Association (AWWA) and Water Environment Federation (WEF), 1998.

[12] FMENV, "National Guidelines and Standards for Water Quality in Nigeria," Federal Ministry of Environment, Abuja, 2002.

[13] WHO, "International Standards for Drinking Water," 4th Edition, World Health Organization, Geneva, 1984.
[14] DOE, "Interim National Water Quality Standards for Malaysia," Department of Environment Malaysia, 2008. http://www.doe.gov.my/index.php?option=comContent \& task=view\&id $=244 \&$ Itemid $=615$ \&lang=en

[15] L. Y. Khuan, N. Hamzah and R. Jailani, "Prediction of Water Quality Index (WQI) Based on Artificial Neutral Network," Student Conference on Research and Development Proceedings, Shah Alam, 2002. doi:10.1109/SCORED.2002.1033081

[16] A. Rim-Rukeh, J. Koyeme, G. O. Ikhifa and P. A. Okokoyo, "Chemistry of Harvested Rainwater in the Refinery Area of Warri, Nigeria between November 2003 and October 2005," International Journal of Chemistry, Vol. 16, No. 2, 2006, pp. 65-74.

[17] RPI, "Environmental Baseline Studies for the Establishment of Control Criteria and Standards against Petroleum Related Pollution in Nigeria," Research Planning Institute, South Carolina, 1985.

[18] F. O. Arimoro, R. B. Ikomi and C. M. A. Iwegbue, "Ecology and Abundance of Oligochaetes as Indicators of Organic Pollution in an Urban Stream in Southern Nigeria," Pakistan Journal of Biological Science, Vol. 3, 2007, pp. 446-453.

[19] A. Rim-Rukeh, "Environmental Science: An Introduction," Kraft Books, Ibadan, 2009.

[20] Y. T. Puyate and A. Rim-Rukeh, "Some Physico-Chemical and Biological Characteristics of Soil and Water Samples of Part of the Niger Delta Area," Nigerian Journal of Applied Sciences \& Environmental Management, Vol. 12, No. 2, 2008, pp. 135-141.

[21] S. Emerson and J. Abell, "The Biological Pump in the Subtropical North Pacific Ocean,” Pretence Inc., Chicago, 2001.

[22] US Department of Interior, "Water Quality Criteria Report," US Department of Interior, Washington DC, 1968.

[23] DPR, "Environmental Guidelines and Standards for the Petroleum Industry in Nigeria," Government Press, Lagos, 2002.

[24] Kentucky Water Watch (KWW), "Dissolved Oxygen and Water Quality," 2001. http://fluid. StatekyUs/www/ramp/rms2.htm

[25] M. P. Cereda and M. C. Y. Matos, "Linamarin: The Toxic Compound of Cassava," Journal of Venomous Animals and Toxins, Vol. 2, No. 1, 1996, pp. 356-361. doi:10.1590/S0104-79301996000100002

[26] F. Berkes, J. Colding and C. Folke, "Rediscovery of Traditional Ecological Knowledge as Adaptive Management," Ecological Applications, Vol. 10, No. 5, 2000, pp. 12511262. doi:10.1890/1051-0761(2000)010[1251:ROTEKA]2.0.C $\mathrm{O} ; 2$

[27] N. J. Turner, M. B. Ignace and R. Ignace, "Traditional Ecological Knowledge and Wisdom of Aboriginal Peoples in British Columbia," Ecological Applications, Vol. 10, No. 5, 2000, pp. 1275-1287. doi:10.1890/1051-0761(2000)010[1275:TEKAWO]2.0.C $\underline{\mathrm{O} ; 2}$ 
[28] C. M. Shastri, D. M. Bhat, B. C. Nagaraja, K. S. Murali and N. H. Ravindranath, "Tree Species Diversity in a Village Ecosystem in Uttara Kannada District in Western Ghats, Karnataka," Current Science, Vol. 82, 2002, pp.
1080-1084.

[29] M. D. McLeod, "The Ashanti," British Museum Publication Ltd., Accra, 1981. 